\title{
Molecular Methodology for the Detection of the Leishmania Genus in Different Biological Samples Extracted from Dogs
}

\author{
Ana Júlia Lopes Miranda Ferreira de Sá', Ellen Laureanny Araújo Olimpo', Vanessa de Andrade Royo', \\ Afranio Farias de Melo Júnior', Dario Alves de Oliveira', Hanna Carolina Campos Ferreira², \\ Alcinei Mistico Azevedo ${ }^{3}$ \& Elytania Veiga Menezes'
}

\begin{abstract}
Background: The leishmaniases are a group of parasitic diseases caused by trypanosomatids belonging to the genus Leishmania, members of the class Kinetoplastida, order Trypanosomatidae, family Trypanosomatidae. Despite innumerous wild species that are infected, the domestic dog is a potential reservoir of Leishmania infantum in urban areas, which expands the transmission pathway to humans. When infected, the dog becomes Visceral Canine Leishmaniasis (CVL), which is characterized by a diverse clinical picture that ranges from asymptomatic to non-specific signs, such as skin lesions, lymphadenomegaly, weight loss, splenomegaly, and/or ocular lesions, thus impairing accurate and rapid diagnosis. In Brazil, it is considered a public health problem since it is endemic in certain regions. Therefore, parasitological, serological, and molecular methods can be used for the detection of the disease. However, the possibility of serological cross-reaction and the occurrence of co-infection with other trypanosomatids decreases the specificity rate to below $100 \%$, which suggests the use of more accurate diagnostic tools. Several molecular targets and starting samples for leishmaniasis diagnosis are already standardized, but there is lack of data allowing the evaluation of the target, as well as which biological material is more efficient for the molecular diagnosis of CVL. The sensitivity of PCR may vary with DNA quality, primer type, parasitemia level, and number of target copies per cell. The spleen, blood, liver, aspirate of bone marrow and lymph nodes are the most frequently used for molecular diagnosis of CVL. The present study aimed to evaluate and compare three protocols of the polymerase chain reaction (PCR) for the molecular diagnosis of CVL in different biological samples removed from animals with different clinical and anatomopathological signs.

Materials, Methods \& Results: Fifty seropositive dogs for CVL were used, their clinical and anatomopathological signs were evaluated, and were classified as asymptomatic, oligosymptomatic, and polysymptomatic. The PCR was conducted with specific primers for each region of the smaller subunit of rRNA, ITS-1, and KDNA genes. The four types of biological samples (spleen, blood, lymph nodes, and liver) were analyzed. Among the 50 dogs studied, 19 (38\%) were in the asymptomatic group; all the animals showed healthy appearance, $15 / 50(30 \%)$ of the dogs presented up to two symptoms, being classified as oligosymptomatic. The polysymptomatic dogs [16/50 (32\%)] presented with a compromised clinical status. The study showed that all dogs had a positive result in at least one analyzed PCR methodology. Comparing the results of the three types of tests in the four types of studied samples, the nested-PCR was the one which presented a greater frequency of amplifications. Of a total of 200 samples, 124 showed amplification, showing a $62 \%$ sensitivity.

Discussion: The results revealed that, when 50 dogs were analyzed, the spleen tissue samples had a better performance in all the tests, but the sensitivity of blood samples was also satisfactory in Nested SSU rRNA-PCR and MC-PCR. The blood samples can be easily accessed with minimal invasion. One of the limitations around the use of biopsy of the spleen or its aspirate is the risk of serious bleeding or even death of the animal. Taking into consideration the practicality and because it has a lower grade of invasiveness, the combination of peripheral blood with Nested SSU rRNA-PCR becomes the methodology of first choice.
\end{abstract}

Keywords: canine visceral leishmaniasis, molecular diagnosis, dogs.

DOI: $10.22456 / 1679-9216.98192$

Accepted: 31 October 2019

Published: 2 December 2019 


\section{INTRODUCTION}

Visceral Leishmaniasis (VL) is considered a public health problem with occurrence in several countries, being Brazil one of the affected [13]. The VL is a zoonosis caused by protozoa of the genus Leishmania [6]. The transmission is given by the vector of the family sand flies of the genus Lutzomyia [14]. In Brazil, the species associated with the transmission of VL is the Leishmania infantum, a synonym for Leishmania chagasi [9].

When infected, the dog becomes Visceral Canine Leishmaniasis (CVL), which characterizes by present a diverse clinical picture, that ranges from asymptomatic to non-specific signs, thus impairing the diagnosis [15].

The clinical diagnosis is difficult due to the disease remains asymptomatic for a long time. The immunoenzymatic assay and indirect immunofluorescence are those recommended by the Ministry of Health [10].

The polymerase chain reaction (PCR) is now a valuable molecular tool for detecting Leishmania $\mathrm{sp}$ in different clinical samples since they are tests that present high sensitivity and specificity [1]. Many targets and molecular initiators for the diagnosis of VL have already been standardized, but there is still a lack of data that allow evaluating which target, as well as which biological material is most efficient for the molecular diagnosis of CVL [18].

In front of a scenario in which VL is one of the neglected diseases that more expands in Brazil and in the world, it is fundamental the development of studies that seek to improve and facilitate the molecular diagnosis of the CVL. Therefore, the objective of this study was to compare three different types of methodologies for PCR that use different DNA targets in the diagnosis of VL.

\section{MATERIALS AND METHODS}

\section{Ethical issues}

In this work, reactive dogs were used in serological tests for CVL diagnosis, which were seized at the Center for Zoonoses Control (CCZ) in Montes Claros (Minas Gerais - Brazil). The present study was evaluated by the Commission for Ethics in Animal Experimentation and Welfare (CEEBEA) of the State University of Montes Claros and received a favorable opinion with case number No 151.

Characterization of the dogs

Among the months from January to March 2018, were collected blood, spleen, lymph node and liver samples from 50 seropositive animals for $\mathrm{LVC}$ in the rapid test and ELISA with a 1:40 titration seized by the Zoonoses Control Center of the municipality of Montes Claros. Before euthanasia, the dogs were evaluated by a trained professional who observed the presence of symptoms such as alopecia, slimming, nail growth, ocular lesions and cutaneous ulcerations. The dogs were classified as asymptomatic without presence of symptoms, oligosymptomatic when they presented at least two symptoms and polysymptomatic when they presented above three symptoms. They were also observed pathological changes in the spleen and liver during necropsy.

Acquisition of the samples

They were removed from the animal, already anesthetized, $5 \mathrm{~mL}$ of punctured venous blood from the cephalic vein using a syringe and tube with the presence of EDTA according to Moraes et al. [11]. After euthanasia, samples of spleen and liver were collected, about $3.0 \mathrm{~cm}^{3}$ and placed in a polypropylene microtube. The lymph node collected was the popliteal. Due to the high sensitivity rate of the PCR technique, all measures to avoid cross-contamination were performed. Samples were refrigerated until arrival at the laboratory and preserved frozen at the temperature of $-20^{\circ} \mathrm{C}[16]$.

The DNA sample that served as positive control was taken from the strain of Leishmania infantum (MHOM / BR / 74 / PP75) available by the René Rachou Researches Center from FIOCRUZ. The negative control was a PCR reaction without the presence of DNA.

\section{Extraction of the DNA}

DNA from blood, spleen, lymph nodes and liver samples was extracted with the use of the phenolchloroform technique [12]. The DNA was kept in the freezer at temperature $-20{ }^{\circ} \mathrm{C}$.

\section{Molecular analysis}

Molecular analysis was performed with the use of three types of PCR methodologies in different DNA targets of the Leishmania parasite (Table 1). The NESTED PCR with the use of an RNA coding region present in the minor ribosome subunit (SSU rRNA); the ITS1 which amplifies a non-coding region of the minor rRNA subunit located between the $5.8 \mathrm{~S}$ and $18 \mathrm{~S}$ genes and the MC-PCR which amplifies conserved sequences from the mini-circle of the kinetoplast. 


\section{Electrophoresis}

The amplified products were separated on $1 \%$ agarose gels stained with Ethidium Bromide and visualized and captured on exposure to ultraviolet (UV) light using UV Gel Logic Transiluminated ${ }^{2}$.
Statistical analysis

The $\mathrm{Z}$ test was used to compare the results among each PCR protocol in the different groups of dogs and among the different samples per protocol of PCR at the level of $5 \%$ of significance.

Table 1. PCR protocols used for LVC diagnosis.

\begin{tabular}{|c|c|c|c|c|}
\hline Protocol / sequence & $\begin{array}{c}\text { Amplification } \\
\text { (bp) }\end{array}$ & PCR Conditions & PCR Cycles & Reference \\
\hline $\begin{array}{c}\text { Nested SSU rRNA-PCR } \\
\text { 1st PCR: } \\
\text { R221: GGTTCCTTTCCTGATTTACG } \\
\text { R332: GGCCGGTAAAGGCCGAATAG } \\
\text { 2nd PCR: } \\
\text { R223: TCCATCGCAACCTCGGTT } \\
\text { R333: AAAGCGGGCGCGGTGCTG }\end{array}$ & 358 & $\begin{array}{c}1^{\text {st }} \mathrm{PCR} \\
3.0 \mu \mathrm{L} \text { DNA, } \\
4 \mathrm{mM} \text { of } \mathrm{MgCl}_{2}, 10 \mathrm{U} \text { Taq Phneutria, } \\
\mathrm{dNTP} 0.33 \mathrm{mM} \text { and } 0.4 \mathrm{mM} \text { of each } \\
\text { primer } 1 \text { Xplug } \\
2^{\text {nd }} \mathrm{PCR} \\
5.0 \mu \mathrm{L} \text { of product of the } 1^{\circ} \mathrm{PCR}, \\
4 \mathrm{mM} \text { of } \mathrm{MgCl}_{2}, 10 \mathrm{U} \text { Taq Phneutria, } \\
\mathrm{dNTP} 0.33 \mathrm{mM} \text { and } 0.4 \mathrm{mM} \text { of each } \\
\text { primer } 1 \text { Xplug }\end{array}$ & $\begin{array}{c}1^{\text {st }} \mathrm{PCR} \\
\text { Denaturation } 94^{\circ} \mathrm{C} 30 \mathrm{~s} \\
\text { Annealing } 60^{\circ} \mathrm{C} 30 \mathrm{~s} \\
\text { Extension } 72^{\circ} \mathrm{C} 30 \mathrm{~s} \\
\text { Final Extension } 72^{\circ} \mathrm{C} 6 \\
\text { min } \\
2^{\text {nd }} \mathrm{PCR} \\
\text { Change only on annealing } \\
65^{\circ} \mathrm{C} 30 \mathrm{~s}\end{array}$ & $\begin{array}{c}\text { Cruz I. et al. } \\
{[5]}\end{array}$ \\
\hline $\begin{array}{c}\text { ITS1-PCR } \\
\text { LITSR: CTGGATCATTTTCCGATG } \\
\text { L5.8S: TGATACCACTTATCGCACTT }\end{array}$ & 311 & $\begin{array}{c}2.0 \mu \mathrm{L} \text { DNA, } \\
2 \mathrm{mM} \text { of } \mathrm{MgCl}_{2}, 10 \mathrm{U} \text { Taq Phneutria, } \\
\mathrm{dNTP} 1.0 \mathrm{mM} \text { and } \\
0.5 \mathrm{mM} \text { primer } 1 \text { Xplug }\end{array}$ & $\begin{array}{c}\text { Denaturation } 95^{\circ} \mathrm{C} 20 \mathrm{~s} \\
\text { Annealing } 53^{\circ} \mathrm{C} 30 \mathrm{~s} \\
\text { Extension } 72^{\circ} \mathrm{C} 1 \mathrm{~min} \\
\text { Final Extension } 72^{\circ} \mathrm{C} 6 \mathrm{~min}\end{array}$ & $\begin{array}{c}\text { El Tai NO et } \\
a l .[21]\end{array}$ \\
\hline $\begin{array}{c}\text { MC-PCR } \\
\text { MC1: GTTAGCCGATGGTGGTCTTG } \\
\text { MC2: CACCCATTTTTCCGATTTTG }\end{array}$ & 447 & $\begin{array}{c}2.0 \mu \mathrm{L} \text { DNA, } \\
3 \mathrm{mM} \text { de } \mathrm{MgCl}_{2}, 10 \mathrm{U} \text { Taq Phneutria, } \\
\mathrm{dNTP} 0.4 \mathrm{mM} \mathrm{e} \\
0.5 \mathrm{mM} \text { primer } 1 \text { Xplug }\end{array}$ & $\begin{array}{c}\text { Denaturation } 94^{\circ} \mathrm{C} 30 \mathrm{~s} \\
\text { Annealing } 55^{\circ} \mathrm{C} 30 \mathrm{~s} \\
\text { Extension } 72^{\circ} \mathrm{C} 20 \mathrm{~s} \\
\text { Final Extension } 72^{\circ} \mathrm{C} 7 \mathrm{~min}\end{array}$ & $\begin{array}{c}\text { Cortes S. et } \\
\quad a l .[4]\end{array}$ \\
\hline
\end{tabular}

Bp: base pairs; PCR: polymerase chain reaction; MC: minicircle; ITS1: internal transcribed spacer 1; rRNA: ribosomal RNA gene; SSU: small subunit.

\section{RESULTS}

Clinical and anatomopathological signs of the dogs

During euthanasia and subsequent necropsy, the dogs were evaluated and classified for the presence of symptoms. Among the 50 dogs studied, $19(38 \%)$ were in the asymptomatic group, all the animals showed healthy appearance, 15/50 (30\%) of the dogs presented up to two symptoms, being classified as oligosymptomatic. Already the polysymptomatic dogs, $16 / 50$ (32\%) presented with the clinical status very compromised. The symptoms analyzed and the frequency in each group is described in Table 2.

From 50 dogs analyzed, 32 (64\%) presented macroscopic lesions in the spleen with apparent granulations, being 14 of them polysymptomatic, 10 asymptomatic and 8 oligosymptomatic. The liver of 17 animals presented alterations, also with presence of granulations and whitish spots. Of these, 8 were polysymptomatic dogs, 6 oligosymptomatic and 3 asymptomatic. 
A.J.L.M.F. Sá, E.L.A. Olimpo, V.A. Royo, et al. 2019. Molecular Methodology for the Detection of the Leishmania Genus in Different

\section{Molecular diagnosis}

Each PCR methodology used presented an amplification product. The NESTED SSUrRNA-PCR with primers 223/333 in 2ndPCR amplified a 358 base pair (bp) DNA fragment (Figure 1).

For the ITS1-PCR protocol, the pair of oligonucleotide used was LITSR, L5.8S that amplify a DNA fragment of 311 base pairs (bp) (Figure 2).

The MC1 and MC2 marker pair amplifies a DNA fragment of 447 base pairs (bp) conserved from the kinetoplast minicircle according to Figure 3.

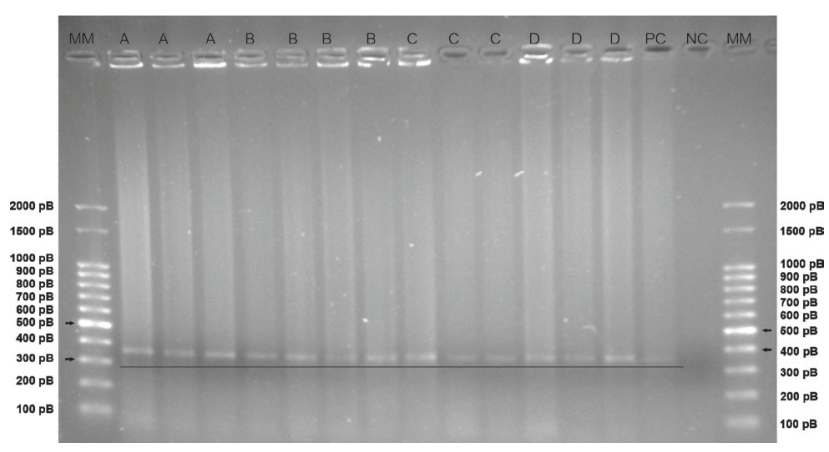

Figure1. 1.0\% agarose gel with products of the NESTED-PCR reaction with the presence of a $358 \mathrm{bp}$ fragment. MM: molecular marker $100 \mathrm{pB}$. A- Spleen samples; B- Lymph node samples; C- Liver samples; D- Blood samples. Positive control CP: Leishmania infantum; CN negative control: mixing of PCR reagents without DNA.

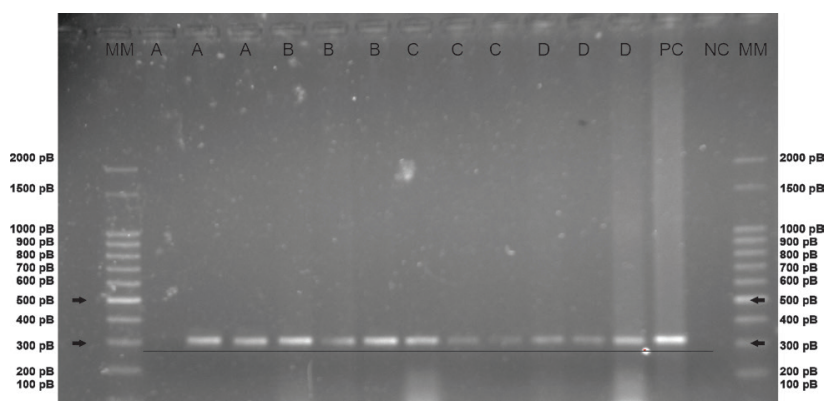

Figure 2. 1.0\% agarose gel with products of the ITS-PCR reaction with the presence of fragment of $311 \mathrm{pB}$. MM: molecular marker 100pB. A- Blood samples; B- Spleen samples; C- Liver samples; D- Lymph node samples. Positive control CP: Leishmania infantum; CN negative control: mixing PCR reagents without DNA.

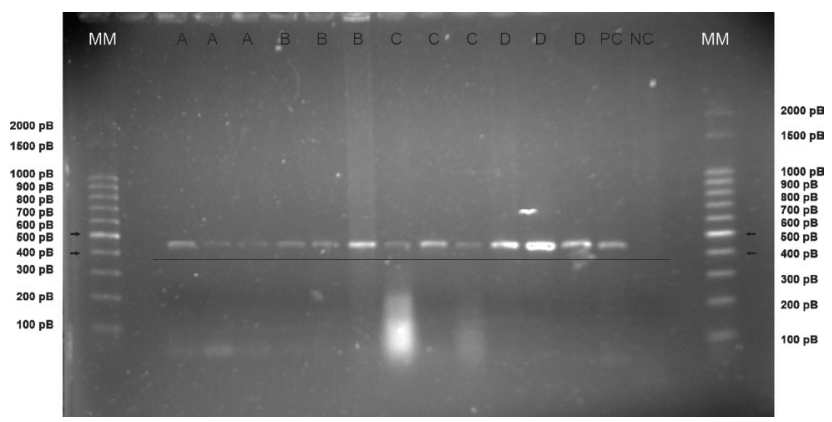

Figure 3. 1.0\% agarose gel with products of the MC-PCR reaction with the presence of fragment of 447pB. MM: molecular marker 100pB. A- Blood samples; B- Spleen samples; C- Liver samples; D- Lymph node samples. Positive control CP: Leishmania infantum; $\mathrm{CN}$ negative control: mixing of PCR reagents without DNA.
Group of asymptomatic dogs

The comparative results of the three PCR methodologies performed on tissues of spleen, liver, lymph node and in blood of asymptomatic dogs are found in Table 3

In this group, only $1 / 19(5.2 \%)$ dog presented the same result for all methodologies evaluated.

When analyzing the three assays, NESTED SSUrRNA-PCR, ITS1-PCR, MC-PCR applied to blood samples, the positivity ranged from $73.68 \%, 47.36 \%$, $63.15 \%$ respectively. When comparing the spleen samples, we noticed an increase in the sensitivity of the tests to $78.94 \%, 57.89 \%, 84.21 \%$. The lymph node samples only presented increase in relation to the other samples in the ITS1-PCR protocol, in which 15/19 (78.94\%) were positive. In counterpart, in the other two tests (MC-PCR and NESTED SSUrRNA-PCR) there was a decrease in lymph node positivity compared to blood and other tissues.

The hepatic tissue was which presented the lowest sensitivity in the three methodologies evaluated with a variation of $26.31 \%$ in the NESTED SSUrRNAPCR and ITS1-PCR to $15.7 \%$ in the MC-PCR.

Only $2 / 19(10.5 \%)$ animals presented negative results in blood in the three PCR assays.

It was observed compatibility in the results of the samples in all the methodologies evaluated. It was observed that in the samples of the splenic tissue there was greater similarity in the positive results and the liver in the negative results (Figure 4).

\section{Group of oligosymptomatic dogs}

It was observed that in the ITS-PCR protocol, $13 / 15(86.6 \%)$ of the dogs presented positive lymph node versus $8 / 15(53.3 \%)$ in the NESTED SSUrRNAPCR and 7/13 (46.6\%) in the MC -PCR.

In the splenic tissue of oligosymptomatic dogs, the methodology that demonstrated the best result was MC-PCR since 13/15 (86.6\%) of them presented amplification products.

In the blood tissue, it was observed a smaller difference between NESTED SSUrRNA-PCR and MC-PCR. Only 3/15 (20\%) of the dogs presented negative results for the blood. The liver tissue presented a $60 \%$ positivity in NESTED SSUrRNA-PCR and 40\% and $26.6 \%$ in ITS-1 and MC respectively (Table 4).

Figure 5 demonstrates the compatibility in the results of the samples in the 3 tests evaluated. In this group of dogs, the greatest similarity was found in the 
blood and lymph node samples with 9 independent coincident results of being positive or negative.

\section{Group of polysymptomatic dogs}

The positivity for LVC in this group in NESTED SSUrRNA-PCR varied greatly, obtaining a better result in blood samples that was of $15 / 16(93.75 \%)$ of the dogs, followed by spleen samples 11/16 (68.75\%), lymph node 8/16 (50\%) and liver 5/16 (31.25\%).

The ITS1-PCR was the molecular test that showed greater efficiency in the detection of infected dogs in spleen samples (15/16) and lymph node $(14 / 16)$; however, in the blood samples were what detected the least number of infected dogs (9/16).

The MC-PCR technique was more efficient in detecting the DNA of the parasite in spleen and blood samples with $87.5 \%$ and $75 \%$ of the dogs respectively. Among the tissues analyzed, the liver was one that presented the lowest detection rate in all techniques. This index ranged from $31.25 \%$ in NESTED SSUrRNAPCR to $18.75 \%$ in the ITS1 and MC-PCR (Table 5).
In this group of polysymptomatic dogs, $3 / 16$ (18.7\%) of them presented the same result for all tissues and blood in the three PCR methodologies used. It was detected the presence of the DNA of the Leishmania sp. in blood samples of the 16/16 (100\%) of the dogs.

Figure 6 demonstrates the compatibility in the results of the samples in the three tests evaluated per sample. Analyzing the data of the figure, it is observed that none of the protocols presented similarity in the negative results in the blood, spleen and lymph node.

All dogs

When analyzing the results of the NESTED SSUrRNA-PCR, MC-PCR and ITS1-PCR in the four types of studied samples in the 50 dogs, the NESTED SSUrRNA-PCR was which presented the highest amount of amplifications. Of the total of 200 samples, 124 amplified, demonstrating a sensitivity of $62 \%$ (Table 6).

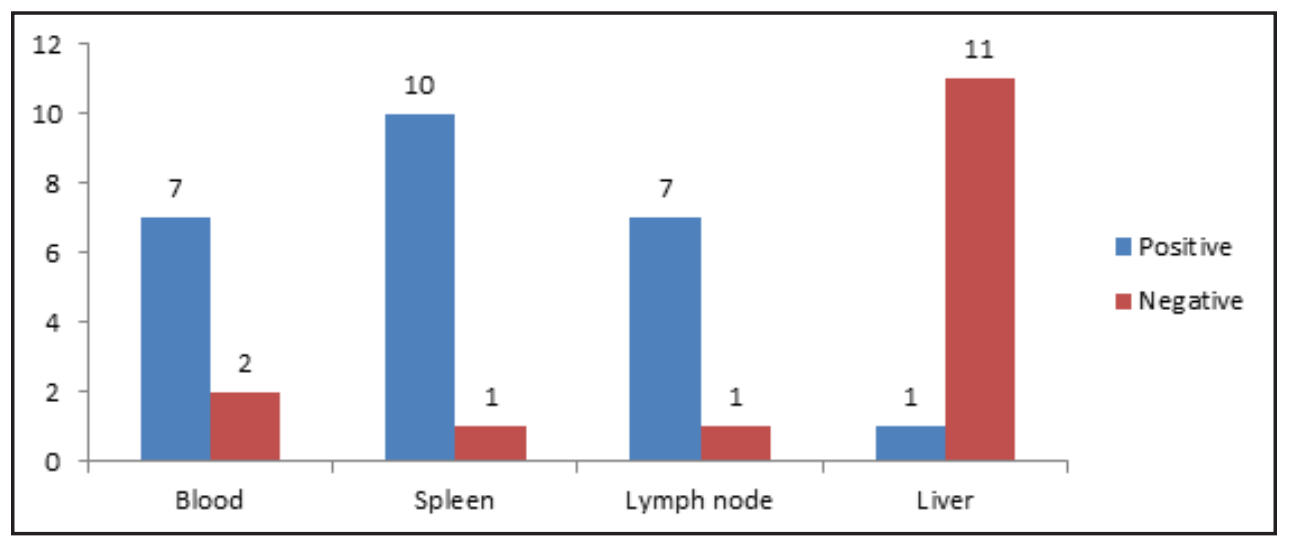

Figure 4. Relation of the compatibility of results per sample in the 3 types of PCR in the group of asymptomatic dogs.

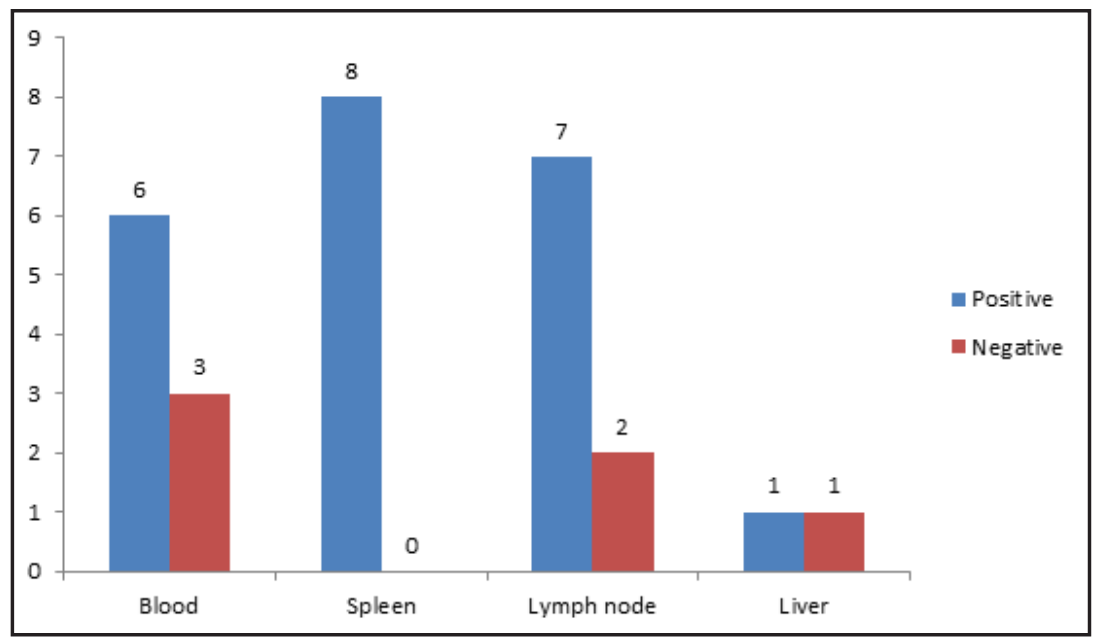

Figure 5. Relation of the compatibility of results by sample in the 3 types of PCR in the oligosymptomatic dog group. 


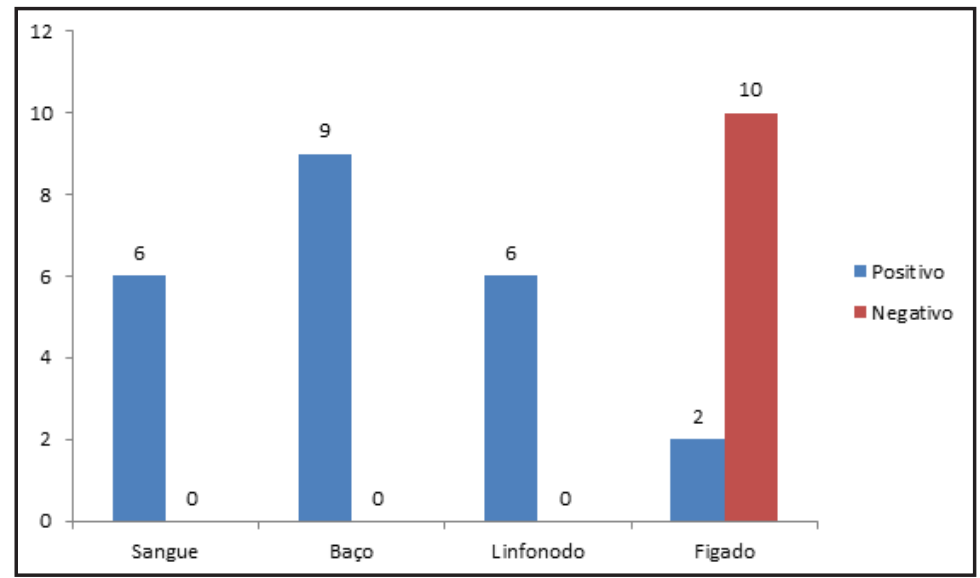

Figure 6. Relation of the compatibility of results by sample in the 3 types of PCR in the group of polysymptomatic dogs.

Table2. Frequency of the symptoms in the three groups of dogs.

\begin{tabular}{cccc}
\hline Symptom & Asymptomatic & Oligosymptomatic & Polysymptomatic \\
\hline Alopecia & $0(0 \%)$ & $5 / 15(33.3 \%)$ & $15 / 16(93.7 \%)$ \\
Onychogrifose & $0(0 \%)$ & $14 / 15(93.3 \%)$ & $15 / 16(93.7 \%)$ \\
Skin ulcerations & $0(0 \%)$ & $7 / 15(46.6 \%)$ & $10 / 16(62.5 \%)$ \\
Weight Loss & $0(0 \%)$ & $4 / 15(26.6 \%)$ & $11 / 16(68.7 \%)$ \\
Eye lesions & $0(0 \%)$ & $0(0 \%)$ & $7 / 16(43.7 \%)$ \\
\hline
\end{tabular}

Frequency in percentage.

Table 3. Results of the PCR analyzes in asymptomatic dogs.

\begin{tabular}{ccccc}
\hline Primer & Blood & Spleen & Lymph node & Liver \\
\hline ITS1 & $9(47.37) \mathrm{Ab}$ & $11(57.89) \mathrm{Aab}$ & $15(78.95) \mathrm{Aa}$ & $5(26.32) \mathrm{Ab}$ \\
NESTED & $14(73.68) \mathrm{Aa}$ & $15(78.95) \mathrm{Aa}$ & $12(63.16) \mathrm{Aa}$ & $5(26.32) \mathrm{Ab}$ \\
MC & $12(63.16) \mathrm{Aa}$ & $16(84.21) \mathrm{Aa}$ & $11(57.89) \mathrm{Aa}$ & $3(15.79) \mathrm{Ab}$ \\
\hline
\end{tabular}

Averages followed by the same capital letter in the column and lowercase in the row, do not differ from each other, according to the $\mathrm{Z}$ test for proportions at the level of $5 \%$ of significance.

Table 4. Results of PCR analysis in oligosymptomatic dogs.

\begin{tabular}{ccccc}
\hline Primer & Blood & Spleen & Lynph node & Liver \\
\hline ITS1 & $6(40) \mathrm{Ab}$ & $9(60) \mathrm{Aab}$ & $13(86.67) \mathrm{Aa}$ & $6(40) \mathrm{Ab}$ \\
NESTED & $10(66.67) \mathrm{Aa}$ & $11(73.33) \mathrm{Aa}$ & $8(53.33) \mathrm{Ba}$ & $9(60) \mathrm{Aa}$ \\
MC & $11(73.33) \mathrm{Aab}$ & $13(86.67) \mathrm{Aa}$ & $7(46.67) \mathrm{Bb}$ & $4(26.67) \mathrm{Ab}$ \\
\hline
\end{tabular}

Averages followed by the same capital letter in the column and lowercase in the row do not differ from each other, according to the $\mathrm{Z}$ test for proportions at the level of $5 \%$ of significance.

Table 5. Results of the PCR assays in polysymptomatic dogs.

\begin{tabular}{ccccc}
\hline Primer & Blood & Spleen & Lymph node & Liver \\
\hline ITS 1 & $9(56.25) \mathrm{Bb}$ & $15(93.75) \mathrm{Aa}$ & $14(87.5) \mathrm{Aa}$ & $3(18.75) \mathrm{Ac}$ \\
NESTED & $15(93.75) \mathrm{Aa}$ & $11(68.75) \mathrm{Aab}$ & $8(50) \mathrm{Bb}$ & $5(31.25) \mathrm{Ab}$ \\
MC & $12(75) \mathrm{ABab}$ & $14(87.5) \mathrm{Aa}$ & $9(56.25) \mathrm{Bb}$ & $3(18.75) \mathrm{Ac}$ \\
\hline
\end{tabular}

Averages followed by the same capital letter in the column and lowercase in the row do not differ from each other, according to the $\mathrm{Z}$ test for proportions at the level of $5 \%$ of significance. 
Table 6. Results of the PCR assays of the 50 dogs.

\begin{tabular}{ccccc}
\hline Primer & Blood & Spleen & Lymph node & Liver \\
\hline ITS1 & $25(50) \mathrm{Ba}$ & $37(74) \mathrm{Ab}$ & $41(82) \mathrm{Ab}$ & $13(26) \mathrm{Aa}$ \\
NESTED & $40(80) \mathrm{Aa}$ & $37(74) \mathrm{Aa}$ & $26(52) \mathrm{Bb}$ & $21(42) \mathrm{Ab}$ \\
MC & $32(64) \mathrm{ABb}$ & $43(86) \mathrm{Aa}$ & $27(54) \mathrm{Bb}$ & $10(20) \mathrm{Ac}$ \\
\hline
\end{tabular}

Averages followed by the same capital letter in the column and lower case in the row do not differ from each other, according to the $\mathrm{Z}$ test for proportions at the level of $5 \%$ of significance.

\section{DISCUSSION}

According to data provided by the Center for Control of Zoonoses of Montes Claros, the period from January 2017 to February 2018, 2659 dogs had positive serology for Leishmaniasis. This data confirms the high index of reservoirs in the disease transmission cycle. Many dogs infected by the LVC may be asymptomatic for a long time [2]. In the present study, 19/50 (38\%) of the dogs were under these conditions and among them only two were not detected the presence of the parasite DNA in the three tests performed. The result demonstrates that even without the presence of symptoms, the dog may be in the pathway of transmission of the disease, since the parasite is present in the blood tissue [1,22].

Among the asymptomatic dogs, (17/19) were positive for the ITS1, (19/19) for the NESTED SSUrRNA PCR and (19/19) for the MC PCR in at least 1 of the samples analyzed. The results demonstrate that the NESTED PCR with primers SSU rRNA and the MC presented $100 \%$ sensitivity in the diagnosis of apparently healthy dogs. The results corroborate with Albuquerque et al., (2017) [1]. who found high positivity for the same methodologies in bone marrow aspirate of asymptomatic dogs.

The analyzes with the use of the molecular target SSU rRNA identify the protozoan Leishmania at the genus level [8]. Already the MC1 and MC2 primers allowed to identify the region of the mini circle of the kDNA, which is usually one of the regions most studied for the diagnosis of LVC, since it is present in several copies per cell. The aforementioned initiators were used by Cortes et al. (2004) [4]. The authors obtained satisfactory results for the diagnosis of canine and human visceral leishmaniasis caused by the species L. infantum and L. donovani.

In the group of asymptomatic dogs, it was found a significant difference in the results of splenic and lymph node tissue in relation to hepatic tissue and blood tissue in the ITS1-PCR protocol. Solcá et al. (2014) [20] in their study suggest that the low sensitivity of these markers in the conventional PCR increases due to the presence of PCR inhibitors in the blood and the low parasitic load.

In the group of the 16 oligosymptomatic dogs, $100 \%$ of them were positive in the three methodologies analyzed in at least one of the samples. It was not observed significant difference between blood tissue and splenic tissue samples in the three PCR methodologies. However, in the lymph node and hepatic tissue samples was observed a significant difference highlighting a higher positivity in these tissues in the ITS1-PCR and NESTED SSU rRNA-PCR assays respectively.

In the group of polysymptomatic dogs, highlight a high positivity in the blood tissue samples in the NESTED SSU rRNA-PCR and in the samples of splenic tissue and lymph node in the ITS1-PCR.

According to the obtained results, when analyzing the $50 \mathrm{dogs}$, the splenic tissue samples performed better in all the trials, however the blood tissue sensitivity was also satisfactory in the NESTED SSU rRNA-PCR and MC-PCR. Blood tissue is a sample that is easier to access and with less invasive obtention. One of the concerns surrounding the use of spleen biopsy or its aspirate is the risk of severe bleeding or even death of the animal [16]. The collection of splenic tissue requires the participation of veterinarian with experience and with deep knowledge of canine anatomy, [3] which makes it difficult to use in an epidemiological inquiry. Therefore, when considering the health risks of the animal, blood becomes the best option for the molecular diagnosis of LVC in these two molecular targets, the NESTED SSU-rRNA and the kDNA.

The MC-PCR methodology used in the present work was performed with primers MC1 and MC2 that were designed specifically for the species L. donovani and L. infantum $[1,4,18]$ The positivity for these 
primers was $49 / 50$ (98\%) of the dogs that presented amplification in at least one of the analyzed samples. The observed result proves that the species prevalent in the city of Montes claros is L. infantum, since it is the species associated with the transmission of CVL in urban areas [19].

The possibility of serological cross-reaction and the occurrence of co-infection with other trypanosomatids makes the specificity rate to be below $100 \%$, which has suggested the use of more accurate diagnostic tools [17]. The study confirmed that there was no difference between the serological results indirect immunofluorescence (RIFI) and immunoenzymatic assay (ELISA) with the adopted PCR protocols, once that $100 \%$ of the dogs researched had positive serology and positive molecular diagnosis in at least one of the analyzed materials and protocols.

According to Dourado (2007)[7] and Silveira et al. (2018) [19] PCR results can be influenced by parasite load, used methodology to DNA purification, primer selection, sample type, and presence of inhibitors. For this reason the difference in sensitivity of each methodology studied.

Regarding the samples, the work demonstrated that spleen and lymph node biopsies are considered efficient for molecular diagnosis of the LVC, since Leishmania infantum tends to migrate to these organs during the course of the disease. However, the risk to the animal should be considered in choosing the bio- logical material to be used. Already the liver tissue was the least reactive in the three groups of analyzed dogs.

\section{CONCLUSION}

The present study demonstrated that the Nested SSU rRNA-PCR methodology is the best choice for the molecular diagnosis of the LVC in both asymptomatic and symptomatic dogs. As this methodology presented satisfactory results for blood tissue samples and taking into account the practicality and being a less invasive collection, this peripheral blood combination with Nested SSU rRNA-PCR was shown in this work the best methodology for the molecular diagnosis of canine Leishmaniasis.

\section{MANUFACTURERS}

${ }^{1}$ Phoneutria Biotecnologia e Serviços Ltda - PHT. Belo Horizonte, MG, Brazil.

${ }^{2}$ Science Park Development Corporation. New Haven, CT, USA.

Acknowledgments. To the Center of Control of Zoonoses of Montes Claros that made possible the collections of the materials. To the René Rachou Research Center from FIOCRUZ for the provision of positive controls.

Ethical approval. The present study was evaluated by the Commission for Ethics in Animal Experimentation and Welfare (CEEBEA) of the State University of Montes Claros and received a favorable opinion with case number No 151.

Declaration of interest. The authors report no conflicts of interest. The authors alone are responsible for the content and writing of the paper.

\section{REFERENCES}

1 Albuquerque A., Campino L., Cardoso L. \& Cortes S. 2017. Evalution of four molecular methods to detect Leishmania infection in dogs. Parasites \&Vectors. 10(57): 1-5.

2 Assis J., Queiroz N.M.G.P., Silveira R.C.V., Maroni N..C, Trícia O., Noronha Junior A.C.F., Neves M.F., Machado R.Z. \& Buzetti W.A.S. 2010. Estudo comparativo dos métodos diagnósticos para Leishmaniose Visceral em cães oriundos de Ilha Solteira, SP. Revista Brasileira de Parasitologia Veterinária. 19(1): 17-25.

3 Barrouin-Melo S.M., Larangeira D.F., Trigo J., Aguiar P.H.P., dos-Santos W.L.C. \& Pontes-de-Carvalho L. 2004. Comparison between splenic and lymph node aspirations as sampling methods for the parasitological detection of Leishmania chagasi infection in dogs. Memórias do Instituto Oswaldo Cruz. 99(2): 1957.

4 Cortes S., Rolão N., Ramada J. \& Campino L. 2004. PCR as a rapid and sensitive tool in the diagnosis of human and canine leishmaniasis using Leishmania donovani s.l.-specific kinetoplastid primers. Transactions of the Royal Society of Tropical Medicine and Hygiene. 98(1): 12-17.

5 Cruz I., Canavate C., Rubio J.M., Morales M.A., Chicarro C., Laguna F., Jiménez-Mejías M., Sirera G., Videla S., Alvar J. \& The Spanish HIV-Leishmania Study Group. 2002. A nested polymerase chain reaction (Ln-PCR) for diagnosing and monitoring Leishmania infantum infection in patients co-infected with human immunodeficiency virus. Transactions of the Royal Society of Tropical Medicine and Hygiene. 96(1): S185-S189.

6 D’Avila-Levy C.M., Boucinha C., Kostygov A., Santos H.L., Morelli K.A., Grybchuk-Ieremenko A., Duval L., Votýpka J., Yurchenko V., Grellier P. \& Lukeš J. 2015. Exploring the environmental diversity of kinetoplastid flagellates in the high-throughput DNA sequencing era. Memórias do Instituto Oswaldo Cruz. 110(8): 956-965. 
7 Dourado Z.F., Silva H.D., Silveira-Lacerda E.P. \& Garcia-Zapata M.T.A. 2008. Panorama histórico do diagnóstico laboratorial da leishmaniose visceral até o surgimento dos testes imunocromatográficos (rK39). Revista de Patologia Tropical. 36: 205-214.

8 Eys G.J.V., Schoone G.J., Kroon N.C. \& Ebeling S.B. 1992. Sequence analysis of small subunit ribosomal RNA genes and its use for detection and identification of Leishmania parasites. Molecular and Biochemical Parasitology. 51(1): 133-42.

9 Lima A.M.V., Santos A.S., Faleiro M.B.R., Moura V.M.B.D, Brito F.L.C. \& Brito L.A.B. 2015. Hystopathology and Leishmania sp. immunostaining in third eyelid of Leishmania (Leishmania) chagasi naturally infected dogs. Ciência Animal Brasileira. 16(4): 538-547.

10 Ministério da Saúde. 2006. Manual de Vigilância e Controle da Leishmaniose Visceral. Brasília: Ministério da Saúde, $122 p$.

11 Moraes P.H.G., Rufino C.P., Reis T., Aguiar D.C.F., Meneses A.M.C. \& Gonçalves E.C. 2014. Optimization of a molecular method for the diagnosis of canine babesiosis. Brazilian Journal of Veterinary Parasitology. 23(1): 105-108.

12 Oliveira M.D.S., Regitano L.D.A., Roese A.D., Anthonisen D.G., Patrocinio E.D., Parma M.M. \& Belicuas S. 2007. Fundamentos teóricos-práticos e protocolos de extração e de amplificação de DNA por meio da técnica de reação em cadeia de polimerase. São Carlos: Embrapa Pecuária Sudeste, 43p.

13 Ortiz R.C. \& Anversa L. 2015. Epidemiologia da leishmaniose visceral em Bauru, São Paulo, no período de 2004 a 2012: um estudo descritivo. Epidemiologia e Serviços de Saúde. 24(1): 97-104.

14 Pimenta P.F.P., Freitas V.C. \& Secundino N.F.C. 2012. A Interação do Protozoário Leishmania com seus Insetos Vetores. In: Tópicos avançados em entomologia molecular. Cap. 12. Rio de Janeiro: UFRJ, 1-45. [Fonte: http://www. inctem.bioqmed.ufrj.br/biblioteca/arthrolivro-1].

15 Ramos R.A.N., Ramos C.A.N. \& Santos E.M.S. 2013. Quantification of Leishmania infantum DNA in the bone marrow, lymph node and spleen of dogs. Revista Brasileira de Parasitologia Veterinária. 22(3): 346-350.

16 Reis L.E., Coura-Vital W., Roatt B.M., Bouillet L.E.M., Ker H.G., Brito R.C.F., Resende D.M., Carneiro M., Giunchetti R.C., Marques M.J., Carneiro C.M. \& Reis A.B. 2013. Molecular diagnosis of canine visceral leishmaniasis: a comparative study of three methods using skin and spleen from dogs with natural Leishmania infantum infection. Veterinary Parasitology. 197(3-4): 498-503.

17 Silva D.A., Madeira M.F., Teixeira A.C., Souza C.M. \& Figueiredo F.B. 2011. Laboratory tests performed on Leishmania seroreactive dogs euthanized by the leishmaniasis control program. Veterinary Parasitology. 179(1-3): 257-261.

18 Silva M.A.L., Medeiros R.A., Brandão-Filho S., Melo F.L. \& Medeiros Z. 2010. Alvos Moleculares usados em PCR para o diagnóstico de Leishmaniose Visceral. Revista Eletrônica de Farmácia. 7(3): 1-15.

19 Silveira A.P.S., Vieira V.B.D., Batalini L.S., Carmo S.B., Friozi E., Arruda E.J., Lima Junior M.S.C. \& NeitzkeAbreu H.C. 2018. PCR sensitivity of peripheral blood of dogs co-infected with Leishmania spp. and Ehrlichia spp. in endemic area of Brazil. Revista da Sociedade Brasileira de Medicina Tropical. 51(6): 843-847.

20 Solcá M.S., Guedes C.E.S., Nascimento E.G., Oliveira G.G.S, Santos W.L.C., Fraga D.B.M. \& Veras P.S. 2012. Qualitative and quantitative polymerase chain reaction (PCR) for detection of Leishmania in spleen samples from naturally infected dogs. Veterinary Parasitology. 184(2-4): 133-140.

21 Tai N.O.E., Osman O.F., Fari M.E., Presber W. \& Schönian G. 2000. Genetic heterogeneity of ribosomal internal transcribed spacer in clinical samples of Leishmania donovani spotted on filter paper as revealed by single-strand conformation polymorphisms and sequencing. Transactions of the Royal Society of Tropical Medicine and Hygiene. 94(5): 575-579.

22 Teixeira A.I.P., Silva D.M., Vital T., Nitz N., Carvalho B.C., Hecht M., Oliveira D., Rabello A. \& Romero G.A.S. 2019. Improving the reference standard for the diagnosis of canine visceral leishmaniasis: a challenge for current and future tests. Memórias do Instituto Oswaldo Cruz. 114(e180452): 1-9. 